\title{
Cytological Studies in the Genus Setaria (Gramineae)
}

\author{
R. V. Singh and P. K. Gupta \\ Cytogenetics Laboratory, Division of Plant Sciences, Meerut University \\ Institute of Advanced Studies, Meerut, India
}

Received January 13, 1976

The genus Setaria belongs to the tribe Paniceae of family Poaceae (Gramineae) and comprises approximately 125 species distributed throughout the temperate, tropical and subtropical regions of the world. The genus has great economic importance and includes cultivated grain crops, perennial forage grasses and noxious weeds. Only about 50 species of the genus have so far been examined cytologically, and most of the studies pertain to scattered chromosome counts of different Setaria species. Recently. the genus was studied in some detail by Khosla and Sharma (1973) who examined eleven Setaria species. The persent communication includes cytology of 29 different Setaria collections representing 18 species.

\section{Material and methods}

The material was obtained through correspondence from different regions of the world and was raised in Botanical Gardens of Meerut University in years 197273. For meiotic study, the spikes were collected in the forenoon and were fixed in Carnoy's fluid (absolute alcohol: chloroform: acetic acid, 6:3:1). A few drops of ferric chloride (saturated solution) were added to the fixative before collecting the material.

Anthers were squashed in $1.5 \%$ acetocarmine. In materials showing abnormal meiosis, unsquashed pollen mother cells were initially studied. Chromosome number and their behaviour was studied from diakinesis to tetrad stage of meiosis. Photomicrographs were taken from temporary preparations. The identification of the material was mainly done by Dr. S. K. Jain of Botanical Survey of India.

\section{Results}

Meiosis was studied in 29 different Setaria collections, representing 18 different species. Chromosome numbers, of different Setaria collections are given in Table 1. For convenience, the available collections were classified into diploids, tetraploids and hexaploids. Results of meiosis are, therefore, presented in these three sections.

\section{Diploid collections}

Among 29 different collections examined nine collections representing nine species were diploid (Table 1). The diploid collections showed normal bivalent formation at metaphase I. Nine bivalents were observed in each case (Fig. 1) except in S. homonyma, where ten bivalents were observed at metaphase I (Fig. 2). 


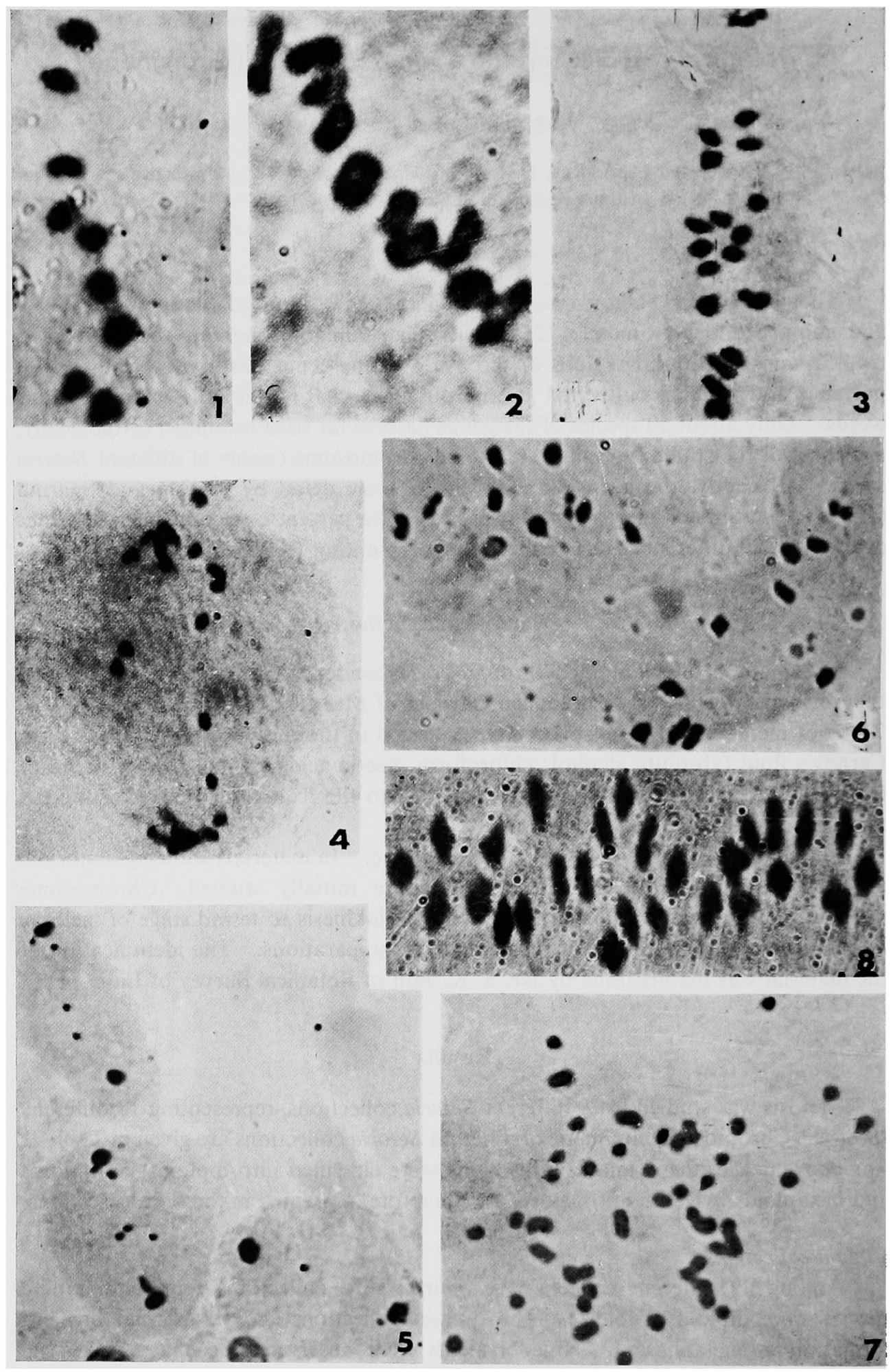


Table 1. Chrmosome numbers in different collections of Setaria

\begin{tabular}{|c|c|c|c|c|}
\hline Taxa & $\begin{array}{l}\text { Colle- } \\
\text { ction } \\
\text { number }\end{array}$ & Source & $\begin{array}{c}\text { Chromo- } \\
\text { somes } \\
\text { number } \\
(n)\end{array}$ & $\begin{array}{l}\text { Ploidy } \\
\text { level }\end{array}$ \\
\hline S. adhaerans (Forsk) Chiov & 45 & Mexico & 9 & Diploid \\
\hline S. alnaspicata & 43 & S. Africa & 9 & Diploid \\
\hline S. argentina Hern & 1587 & Uruguay & 18 & Tetraploid \\
\hline S. chevalieri & 1588 & S. Africa & 18 & Tetraploid \\
\hline S. forbesiana (Nees) Hook. f. & 1590 & India & 18 & Tetraploid \\
\hline S. geniculata (Lam) Beauv. & 60 & U.S.A. & 18 & Tetraploid \\
\hline S. gerardi & 54 & S. Africa & 9 & Diploid \\
\hline S. glauca (L.) PB & 1561 & India & 18 & Tetraploid \\
\hline S. glauca (L.) (Beauv.) & 1560 & India (Chamoli) & 18 & Tetraploid \\
\hline S. homonyma (Steud) Chiov & 1567 & India (Chamoli) & 10 & Diploid \\
\hline S. italica (L.) B & 1589 & India & 9 & Diploid \\
\hline S. macrostachya & 71 & U.S.A. & 27 & Hexaploid \\
\hline S. pallide-fusca (Schum) Stapf. Hubb. & 41 & S. Africa & 9 & Diploid \\
\hline S. pallide-fusca & 1573 & India & 18 & Tetraploid \\
\hline S. palmata (Koening) Stapf. & 1586 & U.S.A. & 27 & Hexaploid \\
\hline S. sphacelata (Schum) Stapf \& Hubb. & 1577 & Australia & 18 & Tetraploid \\
\hline S. sphacelata & 1584 & Australia & 9 & Diploid \\
\hline S. sphacelata & 1585 & Australia & 27 & Hexaploid \\
\hline S. sphacelata & 1574 & Australia & 18 & Tetraploid \\
\hline S. sphacelata & 1575 & Australia & 18 & Tetraploid \\
\hline S. sphacelata & 1581 & Australia & 27 & Hexaploid \\
\hline S. sphacelata & 1576 & Bechuanalnad & $18+1 B$ & Tetraploid \\
\hline S. sphacelata & 1578 & China & 18 & Tetraploid \\
\hline S. tomentosa Rox. Kunth & 1593 & India & 18 & Tetraploid \\
\hline S. tomentosa & 1568 & India (Chamoli) & 18 & Tetraploid \\
\hline S. verticillata & 69 & India & 27 & Hexaploid \\
\hline S. verticulata & 44 & Argentina & 18 & Tetraploid \\
\hline S. viridis & 37 & Iran & 9 & Diploid \\
\hline S. woodii Hack. & 56 & S. Africa & 9 & Diploid \\
\hline
\end{tabular}

Chromosome associations and chiasmata frequencies of these collections are presented in Table 2.

\section{Tetraploid collections}

Fifteen different Setaria collections representing 9 species were tetraploid (Table 1). Meiosis was fairly regular showing 18 bivalents (Fig. 3) in all the collections except in two collections of $S$. sphacelata (Collection Nos. 1574, 1586). These two collections exhibited few minor meoitic abnormalities, which included the presence of laggards at anaphase I (Fig. 4) and anaphase II (Fig. 5) and micronuclei at quartet stage. Frequency distributions of laggards at anaphase $I$ and anaphase II and those of micronuclei at quartet stage are presented in Tables 3, 4 and

Figs. 1-8. 1, S. alnaspicata, metaphase I ( $\left.9^{\mathrm{II}}\right) . \quad 2, S$. homonyma, metaphse I $\left(10^{\mathrm{II}}\right) . \quad 3$, S. argentina, metaphse I (18 $\left.8^{\mathrm{II}}\right) .4, S$. sphacelata (tetraploid), anaphase I showing laggards. 5, S. sphacelata (tetraploid), anaphase II showing laggards. $6, S$. sphacelata, metaphase I $\left(18^{1 \mathrm{I}}+1 \mathrm{~B}\right) . \quad 7, S$. macrostachya metaphase I showing univalents and multivalents. 8, S. sphacelata, metaphase I ( $\left.27^{11}\right)$. 
Table 2. Chromosome associations and chiasmata frequencies at metaphase I in Setaria collections (based in each case on the study of atleast 25 PMCs)

\begin{tabular}{|c|c|c|c|c|c|}
\hline \multirow{3}{*}{ Species } & \multicolumn{3}{|c|}{ Chromosome associations* } & \multicolumn{2}{|c|}{ Chiasmata } \\
\hline & \multicolumn{3}{|c|}{ Bivalents* } & \multirow{2}{*}{$\mathrm{Xta} / \mathrm{PMC}^{*}$} & \multirow{2}{*}{$\underset{\text { (means) }}{\text { Xta/ }}$} \\
\hline & Ring & Rod & Total & & \\
\hline S. adhaerans & $\begin{array}{l}7-9 \\
(8.08)\end{array}$ & $\begin{array}{l}0-9 \\
(0.92)\end{array}$ & 9 & $\begin{array}{c}16-19 \\
(17.24)\end{array}$ & 0.97 \\
\hline S. alnaspicata & $\begin{array}{l}5-9 \\
6.76)\end{array}$ & $\begin{array}{l}0-4 \\
(2.24)\end{array}$ & 9 & $\begin{array}{l}14-19 \\
(16.5)\end{array}$ & 0.92 \\
\hline S. argentina & $\begin{array}{c}16-18 \\
(16.90)\end{array}$ & $\begin{array}{l}0-2 \\
(1.10)\end{array}$ & 18 & $\begin{array}{c}35-40 \\
(35.27)\end{array}$ & 0.97 \\
\hline S. chevalieri & $\begin{array}{l}13-16 \\
(15.70)\end{array}$ & $\begin{array}{l}2-5 \\
(2.30)\end{array}$ & 18 & $\begin{array}{c}28-36 \\
(33.70)\end{array}$ & 0.94 \\
\hline S. forbesiana & $\begin{array}{c}13-17 \\
(16.1)\end{array}$ & $\begin{array}{l}1-5 \\
(1.9)\end{array}$ & 18 & $\begin{array}{l}31-35 \\
(33.2)\end{array}$ & 0.92 \\
\hline S. geniculata & $\begin{array}{l}12-16 \\
(15.92)\end{array}$ & $\begin{array}{l}2-6 \\
(2.08)\end{array}$ & 18 & $\begin{array}{l}30-34 \\
(31.4)\end{array}$ & 0.87 \\
\hline$S$. gerardi & $\begin{array}{l}6-8 \\
(7.60)\end{array}$ & $\begin{array}{l}1-3 \\
(1.40)\end{array}$ & 9 & $\begin{array}{c}15-17 \\
(16.04)\end{array}$ & 0.91 \\
\hline $\begin{array}{l}\text { S. glauca } \\
\text { (Coll no. 1560) }\end{array}$ & $\begin{array}{c}15-18 \\
(16.87)\end{array}$ & $\begin{array}{l}0-3 \\
(1.13)\end{array}$ & 18 & $\begin{array}{c}33-36 \\
(34.44)\end{array}$ & 0.95 \\
\hline $\begin{array}{l}\text { S. glauca } \\
\text { (Coll no. 1561) }\end{array}$ & $\begin{array}{c}16-18 \\
(17.42)\end{array}$ & $\begin{array}{l}0-2 \\
(0.58)\end{array}$ & 18 & $\begin{array}{c}34-37 \\
(35.73)\end{array}$ & 0.98 \\
\hline S. homonyma & $\begin{array}{c}4-10 \\
(7.64)\end{array}$ & $\begin{array}{l}0-6 \\
(2.36)\end{array}$ & 10 & $\begin{array}{l}14-20 \\
(17.0)\end{array}$ & 0.85 \\
\hline S. italica & $\begin{array}{l}8-9 \\
(8.28)\end{array}$ & $\begin{array}{l}0-1 \\
(0.72)\end{array}$ & 9 & $\begin{array}{c}17-19 \\
(17.28)\end{array}$ & 0.96 \\
\hline $\begin{array}{l}\text { S. pallidefusca } \\
\text { (Coll no. 1573) }\end{array}$ & $\begin{array}{l}5-8 \\
(6.93)\end{array}$ & $\begin{array}{l}1-4 \\
(1.07)\end{array}$ & 9 & $\begin{array}{l}14-18 \\
(16.3)\end{array}$ & 0.91 \\
\hline $\begin{array}{l}S . \text { pallidefusca } \\
\text { (Coll no. } 41 \text { ) }\end{array}$ & $\begin{array}{l}15-18 \\
(17.45)\end{array}$ & $\begin{array}{l}0-3 \\
(0.55)\end{array}$ & 18 & $\begin{array}{c}36-41 \\
(38.90)\end{array}$ & 1.06 \\
\hline S. palmata & $\begin{array}{l}24-27 \\
(26.1)\end{array}$ & $\begin{array}{c}0-3 \\
(0.9)\end{array}$ & 27 & $\begin{array}{l}51-54 \\
(52.3)\end{array}$ & 0.96 \\
\hline $\begin{array}{l}\text { S. sphacelata } \\
\text { (Coll no. 1584) }\end{array}$ & $\begin{array}{l}5-9 \\
(7.89)\end{array}$ & $\begin{array}{l}0-4 \\
(0.01)\end{array}$ & 9 & $\begin{array}{c}15-18 \\
(16.54)\end{array}$ & 0.91 \\
\hline $\begin{array}{l}\text { S. sphacelata } \\
\text { (Coll no. 1575) }\end{array}$ & $\begin{array}{c}15-17 \\
(16.76)\end{array}$ & $\begin{array}{l}1-3 \\
(1.24)\end{array}$ & 18 & $\begin{array}{c}33-34 \\
(33.1)\end{array}$ & 0.91 \\
\hline $\begin{array}{l}\text { S. sphacelata } \\
\text { (Coll no. 1578) }\end{array}$ & $\begin{array}{l}16-18 \\
(17.0)\end{array}$ & $\begin{array}{c}0-2 \\
(1.0)\end{array}$ & 18 & $\begin{array}{l}34-36 \\
(34.1)\end{array}$ & 0.94 \\
\hline $\begin{array}{l}\text { S. sphacelata } \\
\text { (Cnil no. 1577) }\end{array}$ & $\begin{array}{c}17-18 \\
(17.76)\end{array}$ & $\begin{array}{c}0-1 \\
(0.24)\end{array}$ & 18 & $\begin{array}{l}35-36 \\
(35.7)\end{array}$ & 0.99 \\
\hline $\begin{array}{l}\text { S. sphacelata } \\
\text { (Coll no. 1574) }\end{array}$ & $\begin{array}{l}15-18 \\
(16.1)\end{array}$ & $\begin{array}{c}0-3 \\
(1.9)\end{array}$ & 18 & $\begin{array}{l}32-36 \\
(34.3)\end{array}$ & 0.95 \\
\hline $\begin{array}{l}\text { S. sphacelata } \\
\text { (Coll no. 1576) }\end{array}$ & $\begin{array}{l}14-18 \\
(16.88)\end{array}$ & $\begin{array}{c}0-4 \\
(1.12)\end{array}$ & 18 & $\begin{array}{c}32-36 \\
(34.64)\end{array}$ & 0.94 \\
\hline $\begin{array}{l}\text { S. sphacelata } \\
\text { (Coll no. } 1581,1585)\end{array}$ & $\begin{array}{r}22-25 \\
(23.6)\end{array}$ & $\begin{array}{l}2-5 \\
(3.4)\end{array}$ & 27 & $\begin{array}{l}49-52 \\
(50.9)\end{array}$ & 0.94 \\
\hline $\begin{array}{l}\text { S. tomentosa } \\
\text { (Coll no. 1568) }\end{array}$ & $\begin{array}{c}12-17 \\
(14.03)\end{array}$ & $\begin{array}{l}4-6 \\
(3.97)\end{array}$ & 18 & $\begin{array}{c}30-32 \\
(31.82)\end{array}$ & 0.88 \\
\hline $\begin{array}{l}\text { S. tomentosa } \\
\text { (Coll no. 1593) }\end{array}$ & $\begin{array}{c}14-18 \\
(15.92)\end{array}$ & $\begin{array}{l}0-4 \\
(2.08)\end{array}$ & 18 & $\begin{array}{c}32-36 \\
(34.08)\end{array}$ & 0.96 \\
\hline $\begin{array}{l}\text { S. verticillata } \\
\text { (Coll no. } 44)\end{array}$ & $\begin{array}{c}12-14 \\
(13.05)\end{array}$ & $\begin{array}{l}4-6 \\
(5.0)\end{array}$ & 18 & $\begin{array}{c}30-32 \\
(30.90)\end{array}$ & 0.86 \\
\hline$S$. viridis & $\begin{array}{l}7-9 \\
(8.13)\end{array}$ & $\begin{array}{l}0-2 \\
(0.86)\end{array}$ & 9 & $\begin{array}{l}16-19 \\
(17.40)\end{array}$ & 0.97 \\
\hline S. woodii & $\begin{array}{l}0-4 \\
(1.72)\end{array}$ & $\begin{array}{c}5-9 \\
(7.44)\end{array}$ & 9 & $\begin{array}{c}9-13 \\
(11.00)\end{array}$ & 0.61 \\
\hline
\end{tabular}

* Upper values are range; Lower values in parentheses are means. 

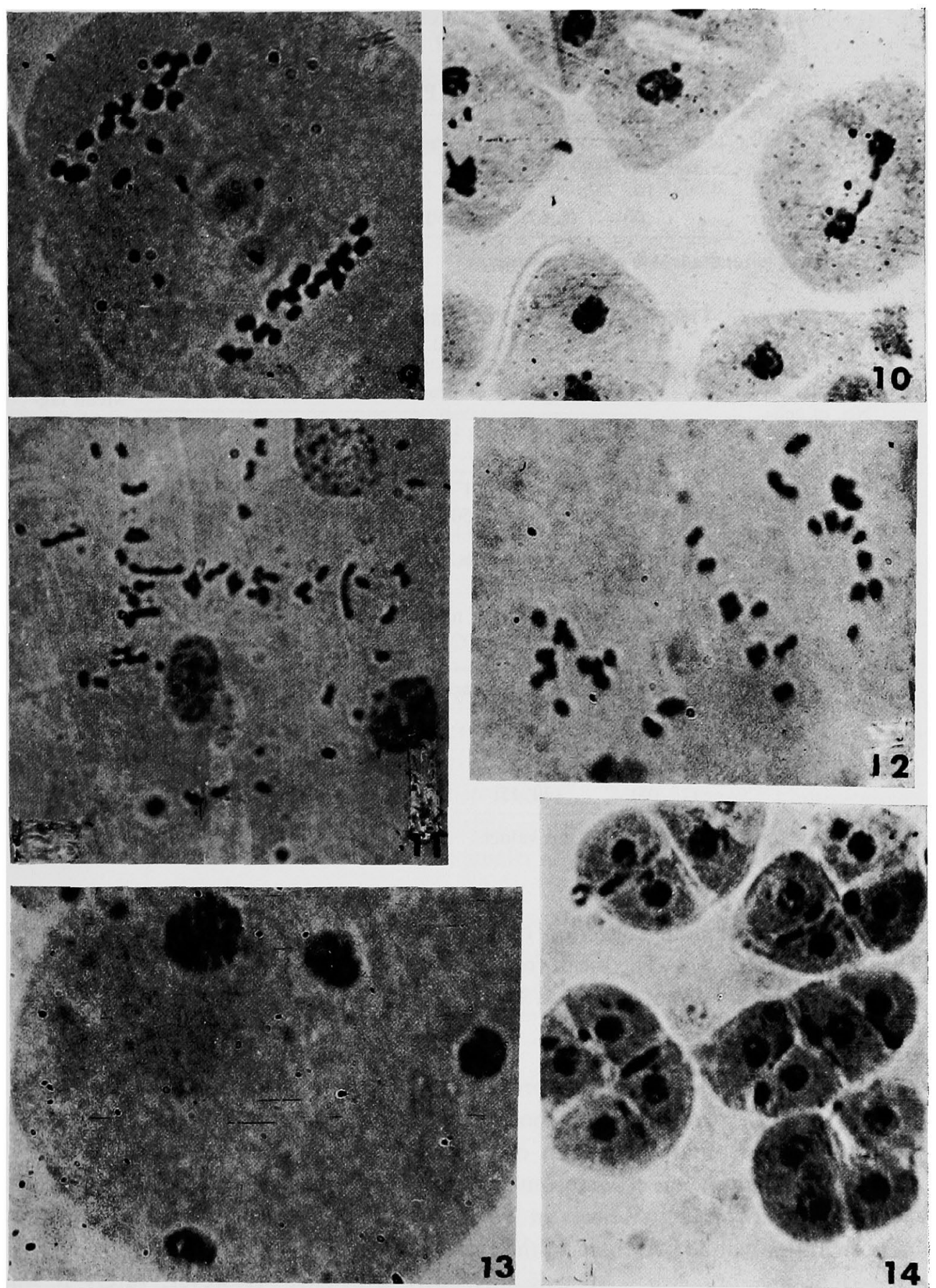

Figs. 9-14. 9, S. sphacelata (hexaploid), anaphase I showing laggards. $10, S$. sphacelata (hexaploid), dyads showing micronuclei. 11, S. verticillata (hexaploid), metaphase I showing bivalents and multivalents. $12, S$. verticillata (hexaploid), anaphase I showing laggards. $13, S$. verticillata (hexaploid), multinucleate condition suggesting multipolar spindles. 14, S. verticillata (hexaploid) showing variety of quartets. 
Table 3. Frequency distribution of laggards at anaphase I in tetraploid S. sphacelata (Coll. no. 1574)

\begin{tabular}{ccccccccc}
\hline \multirow{2}{*}{$\begin{array}{c}\text { No. of PMCs } \\
\text { examined }\end{array}$} & 0 & 1 & 2 & 3 & 4 & $\begin{array}{c}\text { 5 or } \\
\text { more }\end{array}$ & $\begin{array}{c}\text { Mean } \\
\text { laggards } \\
\text { per PMC }\end{array}$ \\
\cline { 2 - 8 } & 10 & 9 & 54 & 7 & 48 & 13 & 2.80 \\
& $(7.08)$ & $(6.67)$ & $(38.29)$ & $(4.89)$ & $(34.04)$ & $(9.21)$ & \\
\hline
\end{tabular}

* Figures in parentheses are per cent values.

Table 4. Frequency distribution of laggards at anaphase II in tetraploid S. sphacelata (Coll. no. 1574)

\begin{tabular}{ccccccccc}
\hline \hline \multirow{2}{*}{$\begin{array}{c}\text { No. of cells } \\
\text { examined }\end{array}$} & \multicolumn{4}{c}{ Frequency of dyad cells with laggards* } & Mean lag- \\
\cline { 2 - 9 } & 0 & 1 & 2 & 3 & 4 & $\begin{array}{c}5 \text { or } \\
\text { more }\end{array}$ & $\begin{array}{c}\text { gards per } \\
\text { dyad cell }\end{array}$ \\
\hline 120 & 16 & 18 & 31 & 32 & 13 & 10 & 2.31 \\
& $(13.33)$ & $(15.00)$ & $(27.50)$ & $(28.33)$ & $(18.33)$ & $(8.33)$ & \\
\hline
\end{tabular}

* Figures in parentheses are per cent values.

Table 5. Frequency distribution of micronuclei in quartets in tetraploid S. sphacelata (Coll. no. 1574)

\begin{tabular}{cccccc}
\hline \hline \multirow{2}{*}{$\begin{array}{c}\text { No. of cells } \\
\text { examined }\end{array}$} & \multicolumn{4}{c}{ Frequency of quartets with micronuclei* } & Mean of nuclei \\
\cline { 2 - 6 } per quartet
\end{tabular}

* Figures in parentheses are per cent values.

5 respectively.

A single tetraploid collection of $S$. sphacelata exhibited the presence of a Bchromosome (Fig. 6). The mean frequency of B-chromosomes was 0.12 per PMC. Chiasmata frequencies are given in Table 2.

\section{Hexaploid collections}

Five collections of Setaria representing four species were hexaploid (Table 1). Except in S. palmata, meiotic abnormalities were recorded in all other hexaploid collections. A solitary collection of $S$. palmata was also found to be hexaploid $(2 n=54)$. Analysis of chromosome associations and chiasmata frequencies are presented in Table 2. Meiosis in other hexaploid collections exhibiting meiotic abnormalities will be presented in the following text.

a) S. macrostachya: Meiosis was fairly irregular. However, rarely it was possible to count 54 chromosomes at metaphase I. Univalents and multivalents were frequent (Fig. 7; Table 6). Abnormal cytokinesis was frequent and was observed in $70.12 \%$ PMC's mainly at dyad stage. Restitution nuclei were also observed in few pollen mother cells at dyad stage. Pollen size varied and pollen diameter ranged from $8.6 \mu$ to $48.6 \mu$, the mean pollen diameter being $25.8 \mu$. Pollen 
Table 6. Analysis of chromosome associations and chiasmata frequency at metaphase I in hexaploid Setaria macrostachya

\begin{tabular}{|c|c|c|c|c|c|c|c|c|}
\hline \multirow{3}{*}{$\begin{array}{l}\text { No. of } \\
\text { PMCs } \\
\text { examined }\end{array}$} & \multicolumn{6}{|c|}{ Chromosome association* } & \multicolumn{2}{|c|}{ Chiasmata } \\
\hline & \multirow[b]{2}{*}{$\begin{array}{c}\text { Uni- } \\
\text { valents }\end{array}$} & \multirow[b]{2}{*}{$\begin{array}{c}\mathrm{Bi}- \\
\text { valents }\end{array}$} & \multicolumn{4}{|c|}{ Multivalents } & \multirow[b]{2}{*}{$\begin{array}{c}\text { Xta/ } \\
\text { PMC* }^{*}\end{array}$} & \multirow{2}{*}{$\begin{array}{c}\text { Xta/ } \\
\text { Chro- } \\
\text { mosome } \\
\text { (mean) }\end{array}$} \\
\hline & & & $\begin{array}{c}\text { Tri- } \\
\text { valents }\end{array}$ & $\begin{array}{l}\text { Quadri- } \\
\text { valents }\end{array}$ & $\begin{array}{l}\text { Penta- } \\
\text { valents }\end{array}$ & $\begin{array}{c}\text { Hexa- } \\
\text { valents }\end{array}$ & & \\
\hline 67 & $\begin{array}{c}5-33 \\
(21.64)\end{array}$ & $\begin{array}{c}3-16 \\
(10.02)\end{array}$ & $\begin{array}{c}0-5 \\
(2.02)\end{array}$ & $\begin{array}{c}0-2 \\
(0.49)\end{array}$ & $\begin{array}{c}0-4 \\
(0.28)\end{array}$ & $\begin{array}{c}0-4 \\
(0.40)\end{array}$ & $\begin{array}{r}19-43 \\
(29.92)\end{array}$ & 0.51 \\
\hline
\end{tabular}

* Upper figures are range and lower fiugre in parentheses are mean values.

Table 7. Frequency distribution of laggards at anaphase I in hexaploid S. sphacelata. (Coll. nos. 1581, 1585)

\begin{tabular}{ccccccccc}
\hline \hline \multirow{2}{*}{$\begin{array}{c}\text { No. of PMCs } \\
\text { examined }\end{array}$} & 0 & 1 & 2 & 3 & 4 & $\begin{array}{c}5 \text { or } \\
\text { more }\end{array}$ & $\begin{array}{c}\text { Mean } \\
\text { laggards } \\
\text { per PMC }\end{array}$ \\
\cline { 2 - 8 } & 26 & 22 & 13 & 1 & 9 & 18 & \\
\hline 89 & $(29.21)$ & $(24.71)$ & $(14.60)$ & $(1.11)$ & $(10.11)$ & $(20.22)$ & 1.98 \\
\hline
\end{tabular}

* Figure in parentheses are per cent values.

fertility was $48.16 \%$.

b) S. sphacelata: Two collections of $S$. sphacelata were found to be hexaploid. In both these collections, 27 bivalents were observed at metaphase I (Fig. 8) and no univalents or multivalents were ever observed. Analysis of chromosome associations and chiasmata frequencies are presented in Table 2. Minor meiotic abnormalities observed at different stages included laggards at anaphase I (Fig. 9; Table 7), laggards at anaphase II (Table 8) and micronuclei at dyad stage (Fig. 10, Table 9).

Table 8. Frequency distribution of laggards at anaphase II in hexaploid S. sphacelata. (Coll. nos. 1581, 1585)

\begin{tabular}{|c|c|c|c|c|c|c|c|}
\hline \multirow{2}{*}{$\begin{array}{l}\text { No. of cells } \\
\text { examined }\end{array}$} & \multicolumn{6}{|c|}{ Frequency of dyad cells with laggards* } & \multirow{2}{*}{$\begin{array}{c}\text { Mean } \\
\text { laggards } \\
\text { per dyad }\end{array}$} \\
\hline & 0 & 1 & 2 & 3 & 4 & $\begin{array}{l}5 \text { or } \\
\text { more }\end{array}$ & \\
\hline 87 & $\begin{array}{c}17 \\
(19.54)\end{array}$ & $\begin{array}{c}14 \\
(16.09)\end{array}$ & $\begin{array}{c}20 \\
22.99)\end{array}$ & $\begin{array}{c}9 \\
(10.34)\end{array}$ & $\begin{array}{c}12 \\
(13.79)\end{array}$ & $\begin{array}{c}15 \\
(17.24)\end{array}$ & 2.34 \\
\hline
\end{tabular}

* Figures in parentheses are per cent values.

Table 9. Frequency distribution of micronuclei in the dyad cells of hexaploid S. sphacelata. (Coll. nos. 1581, 1585)

\begin{tabular}{cccccc}
\hline $\begin{array}{c}\text { No. of cells } \\
\text { examined }\end{array}$ & \multicolumn{4}{c}{ Frequency of dyad cells with micronuclei* } & \multicolumn{2}{c}{$\begin{array}{c}\text { Mean no. of } \\
\text { nuclei per dyad }\end{array}$} \\
\cline { 2 - 5 } & 0 & 1 & 2 & 3 & 0 \\
\hline 91 & 33 & 37 & 21 & 0 & 0.86 \\
\hline
\end{tabular}

* Figures in parentheses are per cent values. 
c) S. verticillata: Meiosis was fairly irregular throughout and meiotic irregularities recorded were mainly of two kinds. The first kind of abnormalties included partial asynapsis resulting in the formation of univalents at diakinesis and metaphase I (Fig. 11), laggards at anaphase I (Fig. 12) and anaphase II and micronuclei at quartet stage. Analysis of chromosome associations and chiasmata frequencies at metaphase I are presented in Table 2. Frequency distribution of univalents at metaphase I, laggards at anaphase I and anaphase II, and micronuclei at quartet stage are presented in Tables $10,11,12$ and 13 respectively.

Table 10. Frequency distribution of univalents at metaphase $\mathbf{I}$ in hexaploid $S$. verticillata. (Coll no. 69)

\begin{tabular}{ccccccccccc}
\hline $\begin{array}{c}\text { No. of } \\
\begin{array}{c}\text { PMCs } \\
\text { examined }\end{array}\end{array}$ & 4 & 6 & 8 & 10 & 12 & 14 & 16 & 20 & 22 & $\begin{array}{c}\text { Mean no. of } \\
\text { univalents } \\
\text { per PMCs }\end{array}$ \\
\hline 25 & 1 & 1 & 7 & 5 & 3 & 3 & 3 & 2 & 1 & \\
& $(4.0)$ & $(4.0)$ & $(28.0)$ & $(20.0)$ & $(12.0)$ & $(12.0)$ & $(12.0)$ & $(8.0)$ & $4.0)$ & 12.16 \\
\hline
\end{tabular}

* Figures in parentheses are per cent values.

Table 11. Frequency distribution of laggards at anaphase I in hexaploid $S$. verticillata (Coll. no. 69)

\begin{tabular}{|c|c|c|c|c|c|c|c|}
\hline \multirow{2}{*}{$\begin{array}{l}\text { No. of PMCs } \\
\text { examined }\end{array}$} & \multicolumn{6}{|c|}{ Frequency of PMCs with laggards* } & \multirow{2}{*}{$\begin{array}{l}\text { Mean laggards } \\
\text { per PMC }\end{array}$} \\
\hline & 0 & 1 & 2 & 3 & 4 & $\begin{array}{l}5 \text { or } \\
\text { more }\end{array}$ & \\
\hline 59 & $\begin{array}{c}30 \\
(50.84)\end{array}$ & $\begin{array}{c}2 \\
(3.39)\end{array}$ & $\begin{array}{c}1 \\
(1.69)\end{array}$ & $\begin{array}{c}3 \\
(5.08)\end{array}$ & $\begin{array}{c}2 \\
(3.39)\end{array}$ & $\begin{array}{c}18 \\
(30.50)\end{array}$ & 3.37 \\
\hline
\end{tabular}

* Figures in parentheses are per cent values.

Table 12. Frequency distribution of laggards at anaphase II in hexaploid S. verticillata (Coll. no. 69)

\begin{tabular}{|c|c|c|c|c|c|c|c|}
\hline \multirow{2}{*}{$\begin{array}{l}\text { No. of cells } \\
\text { examined }\end{array}$} & \multicolumn{6}{|c|}{ Frequency of dyad cells with laggards* } & \multirow{2}{*}{$\begin{array}{c}\text { Mean } \\
\text { laggards per } \\
\text { dyad cell }\end{array}$} \\
\hline & 0 & 1 & 2 & 3 & 4 & $\begin{array}{l}5 \text { or } \\
\text { more }\end{array}$ & \\
\hline 88 & $\begin{array}{c}40 \\
(45.45)\end{array}$ & $\begin{array}{c}2 \\
(2.27)\end{array}$ & $\begin{array}{c}5 \\
(5.68)\end{array}$ & $\begin{array}{c}3 \\
(3.4)\end{array}$ & $\begin{array}{c}5 \\
(5.68)\end{array}$ & $\begin{array}{c}33 \\
(37.5)\end{array}$ & 3.60 \\
\hline
\end{tabular}

* Figures in parentheses are per cent values.

Table 13. Frequency distribution of micronuclei at quartet stage in hexaploid S. verticillata (Coll. no. 69)

\begin{tabular}{ccccccccc}
\hline \multirow{2}{*}{$\begin{array}{c}\text { No. of cells } \\
\text { examined }\end{array}$} & \multicolumn{4}{c}{ Frequency of quartet cells with micronuelei* } & \multicolumn{2}{c}{$\begin{array}{c}\text { Mean no. of } \\
\text { micronuclei } \\
\text { per cell }\end{array}$} \\
\cline { 2 - 9 } & 0 & 1 & 2 & 3 & 4 & $\begin{array}{c}5 \text { or } \\
\text { more }\end{array}$ & \begin{tabular}{c} 
per \\
\hline 76
\end{tabular} \\
\hline & 8 & 15 & 22 & 12 & 11 & 8 & \\
\hline & $(10.50)$ & $(19.70)$ & $(28.90)$ & $(15.80)$ & $(14.47)$ & $(10.50)$ & 2.35 \\
\hline
\end{tabular}

* Figures in parentheses are per cent values. 
The second kind of abnormalities included multipolar spindles and other abnormalities. Multipolar spindles could be inferred from the presence of chromosomes assembled at more than two poles (Fig. 13). These abnormalities were followed by abnormal cytokinesis resulting in different types of tetrads (Fig. 14). Pollen diameter ranged from $8.57 \mu$ to $42.85 \mu$ and mean pollen diameter was $23.90 \mu$. Pollen fertility was $60.77 \%$.

\section{Discussion}

\section{a) Base number}

The chromosome number in Setaria is mainly $n=9$ or its multiple, the ploidy level ranging from diploidy to dodecaploidy. In the tribe Paniceae in general and in Setaria in particular, other base numbers like $x=7,8,10,11,13,15,17$, and 19 are also known, suggesting that polyploidy as well as dysploidy have played important roles in evolution of the genus.

During the present study, all collections studied had chromosome members compounded on $\mathrm{x}=9$ with the solitary exception of a single collection of $S$. homonyma showing $\mathrm{x}=10(\mathrm{n}=10)$. However, $\mathrm{x}=9(2 \mathrm{n}=36)$ is also known in this species (Tateoka 1965, Saxena and Gupta 1970, Khosla and Sharma 1973). The present report in $S$. homonyma, therefore, not only gives a new base number, but also gives a new ploidy level. However, in such reports, it should be realized that the possibility of $n=10$ being actually $x=9+1 B$ can not be ruled out, since the count is based on an individual rather than a population. This is important in view of the fact that in Secale cereale, B-chromosomes are very stable during somatic cell divisions resulting in their presence in all PMCs, their nature mainly being ascertained due to their nondisjunction during pollen mitosis. The other report of $x=10(2 n=$ 44) in S. sphacelata (Mehra et al. 1968) can also be similarly explained, particularly when $2 n=36+1 B$ was observed in this species during the present study.

Further reports of chromosome numbers other than multiples of 9 include $2 n=28$ (Mehra and Shyam Sunder 1970) and $2 n=44$ (Khosla and Sharma 1973) in S. glauca; $2 \mathrm{n}=32$ (Davidse and Pohl 1974) and $2 \mathrm{n}=34$ (Tateoka 1962, Pohl and Davidse 1971) in S. paniculifera; $2 \mathrm{n}=38$ in S. Chondrachne (Ono and Tateoka 1953, Khosla and Sharma 1973), $2 \mathrm{n}=45-52$ in $S$. sphacelata (Hacker 1966) and $2 \mathrm{n}=68$ in S. leucopila (Emery 1957). However, in all these species, counts with $\mathrm{x}=9$ are also known suggesting that the aberrant counts may be derived in nature. In some of these cases, the counts may even represent rare aneuploids rather than established euploids. In these cases, therefore, it may be desirable firstly to ascertain the identity of material and secondly to verify the chromosome count in populations.

\section{b) Polyploidy}

During the present study 20 out of 29 collections examined were polyploids. These 20 collections are represented by 11 species, of which 9 were represented by only polyploids having no diploids. Most of these polyploids exhibited regular meiotic behaviour suggesting their allopolyploid nature, although such a behaviour could also be found in autopolyploids with efficient diploidizing system. 
Meiotic irregularities were, however, recorded in five collections belonging to three species namely $S$. sphacelata, $S$. macrostachya and $S$. verticillata. The irregularities mainly included univalents, laggards and micronuclei, resulting from partial asyndesis as already known in some cases (Snyder 1961, Gupta and Srivastava 1970, 1972). This kind of abnormal meiosis should be genetically controlled and can persist due to perennial nature and/or apomictic mode of reproduction.

In $S$. macrostachya, multivalents on an average involved 11.82 out of $2 n=54$ chromosomes. This may be due to segmental allopolyploidy. Examination of several plants suggested that it can not be due to translocation heterozygosity. Similarly, in $S$. verticillata, spindle abnormalities were observed and can be explained on the basis of a genetic control as known in several other cases (Walters 1960, Gupta and Srivastava 1972).

Some of the chromosome counts during the present study need special mention. Three species, namely $S$. alnaspicata $(\mathrm{n}=9), S$. gerardi $(\mathrm{n}=9)$ and $S$. palmata $(\mathrm{n}=27)$ were cytologically examined for the first time. In two other species i.e. $S$. chevalieri $(\mathrm{n}=18)$ and $S$. homonyma $(\mathrm{n}=10)$ new chromosome counts were obtained.

Three species having chromosome races included $S$. sphacelata $(2 \mathrm{x}, 4 \mathrm{x}, 6 \mathrm{x})$, in $S$. pallide-fusca $(2 \mathrm{x}, 4 \mathrm{x})$ and $S$. verticillata $(4 \mathrm{x}, 6 \mathrm{x})$. In $S$. sphacelata, $5 \mathrm{x}, 8 \mathrm{x}$ and $10 \mathrm{x}$ are also known from published literature. Similarly in $S$. pallide-fusca $8 \mathrm{x}$ and in $S$. verticillata $4 \mathrm{x}$ and $6 \mathrm{x}$ are also known. The availability of chromosome races in the same species raises important taxonomic question i.e. whether or not these can be regarded as separate species particularly in view of the fact that reproductive isolation does exist atleast in some cases. Although experimental taxonomist may suggest that these races should be regarded as separate species, but such separation would hardly serve any useful purpose, unless morphological discontinuities come to exist to enable their identification in the field. Therefore, it is suggested that no new species should be erected on the basis of chromosome numbers alone.

\section{Summary}

1. Meiosis was studied in 29 collections belonging to 18 Setaria species. These included nine diploid collections belonging to nine species, fifteen tetraploid collections belonging to nine species and five hexaploid collection belonging to four species.

2. The diploid collections had $2 n=18$ except in $S$. homonyma where $2 n=20$ was observed. The tetraploid collections had $2 n=36$ and the hexaploids had $2 n=54$.

3. Meiotic irregularities in some polyploid collections were described and discussed.

4. Setaria alnaspicata, S. gerardi and S. palmata were cytologically examined for the first time; new counts were found in S. chevalieri snd S. homonyma.

5. Chromosomal races in $S$. sphacelata, S. pallide-fusca and $S$. verticillata were described and discussed.

\section{Acknowledgements}

Thanks are due to U. G. C. for the award of a fellowship to R. V. S. and to 
The Head, Botany Department, Meerut University for providing the facilities.

\section{References}

Davidse, G. and Pohl, R. W. 1974. Chromosome numbers, meiotic behaviour and notes on tropical American grasses (Gramineae). Can. J. Bot. 52: 317-328.

Emery, W. H. 1957. A study of reproduction in Setaria macrostachya and its relatives in South Western United States and Mexico. Bull. Torrey. Bot. Cub. 84: 106-121.

Gupta, P. K. and Srivastava, A. K. 1970. Breakdown of meiosis in a tetraploid clone from Dichanthium-Bothriochloa complex. Ann. Bot. 34: 1041-1046.

- and - 1972. Aberrant meiosis and spindle abnormalities in Paspalum paspaloides (Michx.) Scribn. (Gramineae), Genetica 43: 76-83.

Hacker, J. B. 1966. Cytological investigations in the Setaria sphacelata complex. Aust. J. Agric. Res. 17: 297-301.

Kholsa, P. K. and Sharma, M. L. 1973. Cytological observations on some species of Setaria. Nucleus 16: 38-41.

Mehra, P. N., Khosla, P. K. Kohli, B. L. and Koonar, J. S. 1968 . Cytological studies in the north Indian grasses. (Part I). Res. Bull. Punjab Univ. (Sci.) 19: 157-230.

- andISunder, Shyam. 1970. Cytological studies in north Indian grasses. (Part II). Res. Bull. Punjab Univ. (Sci.) 20: 503-539.

Ono, H. and Tateoka T. 1953, Karyotaxonomy in Poaceae I. Chromosomes and taxonomic relations in some Japanese grasses. Bot. Mag. Tokyo 66: 18-27.

Pohl, R. W. and Davidse, G. 1971. Chromosome number of Costa Rican grasses. Brittonia 23: 293-324.

Saxena, B. K. and Gupta, B. K. 1970. In IOPB Chromosome number reports. Taxon 19: 437442.

Snyder, L. A. 1961. Asyndesis and meiotic non-disjunction in microsporogenesis of apomictic Paspalum secans. Cytologia 26: 50-61.

Tateoka, T. 1962. A cytoloogical study of some Mexican grasses. Bull. Torrey Bot. Club 89: $77-82$.

- 1965. Chromosome number of some East African grasses. Am. J. Bot. 52: 864-869.

Walters, M. S. 1960. Rates of meiosis, spindle irregularities and microsporocyte division in Bromus trinii $\times B$. carinatus. Chromosoma 11: 167-204. 